\title{
Stress and Change in the Military Profession : Attitudes of Officer Students at the South African Military Academy ${ }^{1}$
}

\author{
LINDY HEINECKEN \\ Centre for Military Studies, University of Stellenbosch
}

\begin{abstract}
In this paper it is illustrated that there is a decline in the commitment to altruistic values if one analyses the survey data of junior officers among all four arms of service at the South African Military Academy. The results show a clear drift towards occupationalism as outlined by Moskos (1977) if the reasons for joining, preferred job characteristics, commitment to selfless service and the need for a representative association are analysed. This trend towards occupationalism could be ascribed to the decline in status and relevance of the armed forces in society, coupled to organisational change, which in placing the military profession under considerable stress in this current period of transition. Some implications of these trends for the military profession are discussed.
\end{abstract}

\section{INTRODUCTION}

Prior to the formation of the South African National Defence Force (SANDF), much of the debate concerning the professionalism of the armed forces centred around the level of expertise, standards and level of training of the former TBVC defence and non-statutory forces to be integration into the new Defence Force. However, by the mid-nineties, this debate had shifted to the more normative aspects of military professionalism. This is reflected in the Constitution of the Republic of South Africa (RSA), the Defence White Paper as well as the various Service Guides for members serving in the SANDF.

The Constitution, for example, stipulates the need for a well trained and disciplined

1 This is an edited version of a paper "Stress and Change in the Military Profession : Attitudes of Officer Students at the South African Military Academy" delivered at the South African Sociological Association Congress, Univeristy of Natal, Durban, 7-11 July 1996. 
defence force, bound by certain codes of conduct. Section 200 (1) states that " $[t]$ he defence force must be structured and managed as a disciplined military force" (2) whose primary objective" ... is to defend and protect the Republic of South Africa, its territorial integrity and its people in accordance with the Constitution and the principles of international law regulating the use of force." (RSA 1996:86) The Defence White Paper goes on to say that "... stable civil-military relations depends to a great extent on the professionalism of the armed forces" and the need to "... build a South African military ethic based on international standards of officership, loyalty and pride in the organisation". (SANDF 1996:14,15) The various Service Guides for members of the SANDF emphasise that the most desirable qualities in individuals who serve in the defence force are loyalty and commitment to serve the nation.

This article attempts to illustrate, that there is a decline in the commitment to many of these normative aspects of military service, particularly the commitment to selfless service if an analyses is made of the responses of junior officers serving at the South African Military Academy. The implication of this trend is that more and more junior officers view soldiering as a job, rather than a calling. It is argued that this increase in occupationalism, is the due to the decline in the status of the military profession in society, coupled to organisational change which is placing the military profession and the continued commitment to the social ethic of selfless service under tremendous stress during this period of transition.

\section{THE SOCIAL ETHIC OF SELFLESS SERVICE}

The concern with the professionalism of the armed forces is just, if one considers that the military can arguably be considered the most powerful institution in any society. The fact that some states are directly governed by military regimes drawn from the officer corps, while others actively strive to ensure that the armed forces remain subordinate to political control, indicates that the question of who joins the officer corps and their motivations for joining, are of central importance to society. (McAllister and Smith 1989:27)

Loyalty and commitment to the service and to the nation are considered to be the most desirable qualities in individuals who are recruited to the officer corps. Because of the unique social function the military is expected to fulfil and the control members of the armed forces exercise over the means of organised violence, society and the military demand a greater degree of personal commitment from members of the armed forces. All in the service of the armed forces are required to demonstrate high standards of patriotism, discipline, courage and self-sacrifice in the course of their duties, and to demonstrate a responsibility to use their skill in the interests of society. (Huntington 1957:13, Downes 1985:158)

Given these requirements, it is considered contrary to the professional ethics and standards of the professional soldier to organise into interest groups (such as trade unions) to 
advance their own financial rewards, or to use their armed might against the state to advance the interests of the military establishment. As the SANDF must at all times be capable of and ready to fulfil its constitutional obligations, its members are expected to make certain sacrifices due to the unique nature of armed forces and military service. In an Internal Communication Bulletin of the SANDF, for example, it is stated that members of the SANDF must submit to the basic ethics of soldiering and accept that certain fundamental rights such as the principle of freedom of association, freedom to assemble, the right to demonstrate or strike and the right to live may have to be sacrificed. (CSANDF 1995:73) This sacrifice is made " ... in the interests of preserving those fundamental rights for all citizens who are not in the service of the military". According to the SANDF, the limitations on these fundamental rights are reasonable and justifiable in an open and democratic society as the Defence Force must be ready to serve the nation at any time. (SANDF 1994:15, CSANDF 1995) Should individual self-interest be placed above duty and service in the SANDF, it is considered "a misplaced military ethic". (SANDF 1994:3) As employment in the military is considered a profession, members are expected not to place emphasis on pay and conditions of employment, as does the person who views his work merely as a job.

However, in the past few decades the military profession world-wide has come under tremendous stress, not only as a result of the changing nature of the military profession, but also as a result of a global decline in the status of the military profession. Armed forces suddenly found themselves having to justify their existence and the expenditure they receive, and this has had a profound impact on the attitude of soldiers towards their employment in the military. Already in the seventies, Moskos (1977) identified that the military social organisation world-wide was undergoing an institutional/occupational drift where professional orientations (legitimated in terms normative values), were being replaced by occupational orientations (legitimated by marketplace values). Implicit in this formulation is that the soldier's view towards employment in the military was undergoing change - from viewing military service as a calling, or vocation, to viewing their employment in the military as just another job. The more occupational the officer, the greater the importance ascribed to factors such as salary, job security or general working conditions, indicating a priority with self-interest rather than that of the employing organisation. A similar trend towards occupationalism was found among junior officers at the S.A. Military Academy.

2 Segal and Lengermann (1980:165) indicate that research in the U.S. Air Force reveals that more senior ranks and combat personnel show a higher sense of calling and a low sense of job, while lower ranks (such as junior officers) show a low sense of calling and a high sense of job orientation. Moskos (1986:381) too acknowledges that I/O modalities may vary between officers, non-commissioned officer and lower ranks. 


\section{VALUE ORIENTATIONS OF JUNIOR OFFICERS}

While it is accepted that there may be a difference between senior and junior personnel, ${ }^{2}$ the results obtained from a survey conducted among junior officers at the S.A. Military Academy in November 1995 to measure I/O orientations, substantiates that there is a significant change in value orientations with respect to those aspects of military service that have traditionally been regarded as core dimensions of officers' professional identity, if an analysis is made of the reasons why the junior officers at the Military Academy joined the Defence Force; preferred job characteristics; personal attitudes towards aspects of military service; and the need for an association to represent the interests of members. The value of the Military Academy case study is that it represents an elite group of junior officers from all arms of service, "... the best and the brightest ..." who will set the future standards of professional behaviour, and eventually go on to fill the top posts in the SANDF. For this reason it is particularly important to take cognisance of the level of commitment and attitude of these officers towards their employment and future careers in the SANDF.

\section{Reasons for joining the military}

Who joins the officer corps and their reasons for joining is important to all societies, as the leadership role of the officer corps has significant implications for the character and stability of the political system. (McAllister and Smith 1989:27) Loyalty and commitment to the service and to the nation are considered the most desirable qualities in individuals who are recruited to the officer corps. As indicated in the Defence White Paper, the same qualities are desired from those serving in the South African military.

\section{Variable}

Important

$\%$

78.7

78.7

60.7

32.2

25.3

14.2

8.2
Unimportant

$\%$

- Secure job with promotion and favourable retirement benefits

- Liking for discipline, orderliness, uniformity etc

- Liking for the military : weapon systems etc

- Believe in need for a strong defence force

- Service in the defence force is a calling

- Continue a family tradition of military service

- Could not adapt to a civilian career

Source : Heinecken and Khanyile (1996:13)

Table 1 : Reasons for joining the military (in percentages). 
Yet, very few of the officers at the Military Academy indicated that they joined the Defence Force for patriotic reasons. Only a quarter considered military service a calling or believed in a need for a strong defence force. They did not consider themselves " militarists at heart" or thought that "the strength of a nation's greatness is determined by military power". This could possibly be ascribed to the absence of any immediate threat to the South African state.

A secure job with good fringe benefits, together with a liking for discipline, orderliness, uniformity, cohesiveness, unit pride and interest in military weapon systems, ships, aircraft and military operations served as the main motivation in selecting a military career. The fact that they chose the military as a career even though they felt comfortable that they could easily adapt to a civilian career, indicates that both occupational and institutional factors influenced the decision to join the permanent force.

\section{Features of a preferred job}

A similar trend was identified to the responses of the features of a preferred job. One of the distinguishing characteristics of a profession, compared to that of an occupation is the commitment to selfless service. The most significant sign of altruism is the subordination of individual financial rewards to the goals of serving society.

The responses to the above questions affirm that the greatest importance is assigned to features such as a good salary, job security with no chance of summary dismissal and good fringe benefits. Traditional institutional values such as " a job that gives me a chance to make the world a better place to live in" and a "job that gives me a chance to serve my country" rated the least important on this scale. Similar trends were identified in the United States armed forces in a study by Segal (1978:230) measuring certain preferred job characteristics between army, navy and civilian personnel. In all three work environments personnel regarded good pay, fringe benefits, the opportunity to control their personal

Variable

Important

$\%$

96.7

85.2

94.5

71.6

56.8
Unimportant

$\%$

- A job with a good salary

- A steady job with good security

- A job with good fringe benefits

- A job where you can make the world a better place

- A job where I can serve my country

Source : Heinecken and Khanyile (1996: 12)

Table 2: Most and least important features of a preferred job (in percentages). 
lives and the avoidance of bureaucracy as the most preferred job characteristics. On the other hand such factors as prestige, job cleanliness, availability of free time, not being bossed and an opportunity to serve the country were relatively less important.

However, while the marketplace values were the most preferred, institutional values were not unimportant features of a preferred job. A significant proportion still regarded service to the nation as an important feature of military service, even in the absence of an immediate military threat to the country. This indicates that while there is a high tendency towards occupationalism, officers are still committed to traditional institutional values, reflecting a kind of pragmatic professionalism. According to Caforio and Nuciari (1994:37) these responses are typical of the "pragmatic professional officer" who maintains traditional and ideal professional values, but at the same time stress a strong interest in job security, transferability of skills and the public image of the profession.

\section{Commitment to selfless service}

As military service has traditionally been congruent with notions of self-sacrifice and primary identification with the military's needs, individual interests have been subservient

Variable

Agree Disagree

$\% \quad \%$

- Not have to take a transfer if don't want it

- Perform operational duty regardless of personal family consequences

- Personal interests take second place to defence force

- What a member does after hours not Defence Force business

- Differences in rank not important in members social life

- Members private life of no concern officer commanding

- Concept officer on duty 24 hours a day no longer valid

- Compensation based on skills and qualifications and not on post level, rank and seniority

- Think of myself as person with special training working for the defence force

- My military training, qualifications, expertise and experience is more important than my officership
67.0

45.4

79.8

66.1

78.7

21.3

58.5

77.2

71.3

71.1

Source : Heinecken and Khanyile (1996:14)

Table 3 : Personal attitudes towards aspects of military service (in percentages). 
to the interests of the military. In fact, the SANDF "Service Code for Officers" states that placing individual self-interest above duty and service is considered a "misplaced military ethic". Military members must accept that they cannot unilaterally terminate their employment, are subject to transfers and frequent relocation of themselves and their families, are on duty 24 hours a day, often have to work longer than an eight hour day, and are subject to military discipline and law. Even the private lives of members are under the purview of the military and governed by a code of personal conduct. (SANDF 1994:3)

Despite these principles, there appears to be a growing tendency towards occupationalism where it pertains to the individual's needs versus those of the military organisation. Most of the officers were of the opinion that they should be given a choice whether to accept a transfer or not, and should not have to perform operational duties if this negatively impacts upon personal and family interests. Nor should personal interest and wishes take second place to the interests and requirements of the Defence Force.

With respect to their personal lives, the overwhelming majority were of the opinion that what a member does after hours is none of the Defence Force's business, that differences in rank are not important after hours and what a member does in his private life should be of no concern to his/her officer commanding. Concerning overtime, or the concept of an officer being on duty for 24 hours a day, more than half of the respondents were of the opinion that this is no longer a valid requirement in teday's military.

When asked "whether they normally think of themselves as a person with special training and experience working for the Defence Force rather than as a military career officer" (military professional), most agreed with this view. This perception was reinforced by the notion that compensation should be based on one's skills and qualifications and not on post level, rank and seniority. Furthermore, that military training, qualifications, ex-

\begin{tabular}{|lcc|}
\hline Variable & $\begin{array}{c}\text { Agree } \\
\%\end{array}$ & $\begin{array}{c}\text { Disagree } \\
\%\end{array}$ \\
\hline - Need for representation on highest level on pay and & 93.4 & 6.6 \\
$\begin{array}{l}\text { promotion } \\
\text { Need for a legal representative to take pay problems } \\
\text { to court }\end{array}$ & 82.3 & 17.7 \\
- Need for a representative association & 91.2 & 8.8 \\
- Opposed to representative association bypassing the & 35.9 & 64.1 \\
$\begin{array}{l}\text { existing chain of command to negotiate } \\
\text { Interests of members are well look after by headquarters }\end{array}$ & 16.1 & 83.9 \\
\hline
\end{tabular}

Source : Heinecken and Khanyile (1996:15)

Table 4 : Need for a representative association (in percentage) 
pertise and experience acquired during military service is more important than their officership in determining their standing in the Defence Force. This signifies an overall trend away from those who identify themselves as military professionals, toward those who see themselves as specialists in uniform. A movement away from military professional to that of a professional in uniform.

\section{Need for a representative association}

Traditionally it has been considered contrary to the professional ethics and standards of the professional soldier to organise into interest groups (such as trade unions) to advance their own financial rewards.

The responses to the questions relating to the need for some form of external organisation to represent the interests of members with respect to pay and promotion, reveal that the majority of officer students felt that some form of mild collectivism, such as an association (not a trade union) was needed to represent and negotiate on their behalf outside the chain of command. In addition, there appears to be a general feeling that the chain of command can no longer be relied upon to protect the interests of individual members. The mere fact that only 16 percent felt that their interests were well looked after by the respective headquarters and staff divisions, indicates a relatively high level of dissatisfaction with some aspects of the military's ability to handle personnel problems. In this regard Moskos and Wood (1988:288) state that " $[\mathrm{t}]$ o the degree that military members perceive senior military leaders as ineffective defences of an institutional compensation system, creeping occupationalism will appear in the rank and file."

One of the reasons for the need for an outside organisation to place pressure on both the military command structure as well as the political decision makers, is precisely because most sources of grievances cannot readily be addressed within the chain of command. The required decisions are often beyond the legal competence of the officer commanding or the internal authority structure of the military, as will be explained in due course.

\section{SOCIETAL TRENDS PROMOTING OCCUPATIONALISM}

The Heinecken and Khanyile (1996) study focused primarily on micro-level attitudinal change, without due acknowledgement of possible macro-level societal influences, or mesolevel organisational changes that could have influenced the interpretation of the institutional/occupational trends among junior officers. It is believed that the ascendancy in occupationalism among the junior officer corps, is the consequence of societal as well as organisational pressures and that these tends are having a significant impact on all employed in the SANDF.

The concept of professionalism, as applied to the military implies that military officers 
have to acquire a sense that they are acting in an area of vital concern to society and need to be convinced that society, in turn, accords them the necessary respect, confidence, and prestige. (Kuhlmann 1994:87)

Where there is a decline in the interest in the military in society, this has major implications for those employed in the armed forces. In this regard Weibull (1994:70) is of the opinion that where "[t]he external world's view of the officer's job, here defined as the sum effect of how politicians value military expertise in relation between missions and means and the image of the officer's profession in the public eye, is judged as the most dissatisfying factor ... and where one's contribution is supposed to add much to the common good, the strong dissatisfaction with feedback from society must be looked upon as a warning concerning officers ' future commitment to their work." Commitment to altruistic values depends upon reinforcement from society. Where this is not forthcoming, soldiers are unlikely to view their service in the military as a calling.

Harries-Jenkins (1977:61) supports this view, claiming that one of the most important factors motivating behaviour based upon self-interest is the feeling that the armed forces compared to other institutions in society have lost their previous status and have suffered an undue amount of deprivation. "When there is a significant loss of privilege and status of the military in society, trade unions are then formed as a pressure group to re-establish the privileges formerly held by the armed forces". Such a development naturally poses a threat to civil-military relations, especially where the interests of the military trade union runs counter to public interest.

Since the end of the Cold War and the related border war, the Defence Force no longer enjoys the same privileged position and influence in decision-making in state structures as during the seventies and eighties. With no clear threat perception state priority has shifted from security to social development and upliftment. While the integration of the various homeland and non-statutory forces into the new SANDF has enhanced the legitimacy of the military among the broader population, the absence of any immediate threat has created the impression that the military is becoming less important and military service less appreciated by civilian society. Further cuts in the defence budget, coupled to public debates over whether there is a need for a technologically advanced defence force reinforce the sense of insecurity felt amongst military personnel.

\section{ORGANISATIONAL CHANGE PROMOTING OCCUPATIONALISM}

Certain changes within the military organisation too have contributed towards the increase in self-interest behaviour. The shift from conscription to voluntarism, where the military must rely to a large extent on individuals to join the military voluntarily has significant implications for the military as employer. Under a volunteer system, the military is compelled to take marketplace criteria into consideration if quality personnel are to be recruited and retained. Factors that influence the relative attractiveness of enrolment in 
the military on a voluntary basis are pay, service benefits and the availability of alternative employment opportunities. Many join not because of the uniqueness of military service, but for other reasons such as tertiary education or job opportunities that provide the financial and promotional prospects needed to attain material success. (Heinecken 1994:36) The fact that there is a greater willingness among military personnel under a volunteer system to draw comparisons and claim greater parity with civilian counterparts, increases the trend towards occupationalism.

The emphasis on market incentives during recruitment without emphasising the unique features of military service, too has contributed towards the occupationalism of military service. What this suggests, is that while market forces are important to attract and retain high quality personnel, the uniqueness of military service must be emphasised in recruitment campaigns if members are to demonstrate a commitment to altruistic norms. Should only marketplace criteria be emphasised, it can be expected that members would be more likely to adopt civilian-type labour practices to prevent any erosion of possible benefits.

Another important factor with respect to recruitment in the volunteer force, is the shift in the profile of recruits from elites, to representing the broader population. According to Caforio and Nuciari (1994:54) occupational officers more frequently come from lowerstatus groups who choose to join the military for job security or educational opportunities that will provide the financial and promotional prospects needed to attain material success. With the termination of whites only conscription the majority of recruits now entering the SANDF come from disadvantaged backgrounds.

The predominantly black, homeland armies have also brought with them a number of potentially dangerous legacies. Most of these officers have tasted political power as an effective way of satisfying their demands. The lack of political legitimacy as well as the inability to deliver on the economic front caused much of the instability in these former self-governing territories. In fact, the inability to deliver on the economic front has been one of the main causes of coup d'etats in Africa. (Reichart and Cilliers 1996:82) Many of these soldiers have experienced the benefit of trade unionism. The actions of 800 Umkhonto weSizwe soldiers who went on strike over money owed to them by the National Peacekeeping Force, indicates the willingness to act in self-interest. (Heinecken 1994:37,38) One may therefore expect that the inclination towards self-interest behaviour will increase should there be a further decline in the legitimacy and service conditions of military personnel.

The present reduction in manpower or downsizing of the armed forces have contributed to the trend towards occupationalism. Personnel costs make up roughly half of most defence budgets, with the result that military members have become highly vulnerable to marketplace phenomena such as redundancy and rationalisation when budgetary cuts are implemented. In a study by Wrong and McNally (1994:209) it was found that there was a significant decrease in organisational commitment after downsizing began among those who remained behind or had supposedly made it. Currently, there is great concern among 
those who wish to remain in the SANDF regarding their own relationship with the military, their future careers and the caretaking provisions that will be provided for those who will be forced to leave.

The trend towards occupationalism among the largely white junior officer corps at the Military Academy, too can be directly related to economic factors - the decline in tenure, together with the progressive erosion of service benefits. Although in real terms soldiers are not remunerated at the same level as civilians, their situation is ameliorated by a range of institutional benefits such as cheaper housing, uniform allowances, military transport and free medical services. In recent years there has been a rapid erosion of these benefits. To name but a few, the duty bus benefit has been discontinued, accommodation tariffs have been substantially increased, subsistence and travel allowances for sport have been discontinued, some benefits have become taxable and others, such as clothing and homeownership allowances have lagged behind market increases, not to mention pay increases. In the past, the economic disadvantages of military service were partially offset by the extensive fringe benefits that formed part of the compensation package of the implied service contract of the soldier.

Of interest is that in the Australian Defence Force, it was precisely the inability of the system to protect the interests of service members which contributed to the formation of the Armed Forces Federation of Australia. Even though Australian officers felt that unionism and the military did not mix, they nevertheless believed that it was the only effective means to prevent a further decline in their service conditions. (Jans 1988:216) Moskos and Wood $(1988: 288)$ too are of the opinion that "... the degree that military members perceive senior military leaders as ineffective defenders of an institutional compensation system, creeping occupationalism will appear in the rank and file". A similar trend was identified by Heinecken and Khanyile (1996), where the majority of officer students felt there was a need for an association to represent and negotiate on their behalf outside the chain of command.

This need for a representative association can in part be attributed to the changing national labour-relations climate where other professional groups (teachers, nurses, police) have organisations which can represent their interests. The conditions of service for the rest of the Public Service, including civilians in the full-time forces are represented by trade unions and/or personnel associations. However, uniformed personnel have no official representation on the Public Service Central Bargaining Council which means that there is no forum where the military leadership can directly negotiate or bargain for the unique service conditions of soldiers. As a result, the Defence Force has to accept without any recourse the results of the agreements reached for the broader Public Service. The Public Service Commission has also been insensitive to the unique institutional needs of the military and tends to treat military personnel in the same manner as the rest of the public service. The lack of representation and inability of the system to protect its unique compensation system, has resulted in further pressure to form labour unions or some para- 
union structure. An internal attitude and opinion survey revealed that fifty percent of respondents believed that there is a role for unions in South Africa, and that should there be a union for the SANDF, that they would join.

\section{SUMMARY AND CONCLUSIONS}

According to Downes $(1985: 159)$ the military profession, more than any other profession must convince society and the government that the profession is motivated by the social ethic of selfless service.

The fact that military personnel are in general very similar to their civilian counterparts in what they would like from their jobs, has signalled a change in the value orientations of military professionals. Most seem to be turning away from reference patterns based on common good, to individualistic patterns in career and job security like any other occupation. (Nuciari 1994:8-9)

This global trend among military personnel is also evident in South Africa and is reflected in the reasons for joining the permanent force and the most preferred job characteristics The greatest importance is assigned to occupational features such as a good salary and job security. Traditional values such as a chance to serve one's country and a chance to make the world a better place, were rated least but not unimportant, reflecting a kind of pragmatic ${ }^{2}$ professionalism.

In a social system where money and power are seen as the indicators of success and where society no longer holds the military profession in high esteem, despite their commitment to serve society, one cannot expect otherwise. Such a value system based on material incentives is almost totally at odds with the values that have traditionally been regarded by the military as imperative to their operational efficiency - that of loyalty and commitment to the goals of the organisation. (Downes 1985:196)

One might therefore expect that a significant proportion of recruits are choosing to join the military for occupational reasons, such as the expertise and financial rewards it brings the individual. Consequently, one could anticipate that these reasons for joining have distinct implications for the professional values of the individual and for their probable length of service. Thus an individual who joins for occupational reasons would probably stay committed to the military only as long as the military can provide a salary and working conditions commensurate with other professions. (McAllister and Smith 1989:31)

Commitment of an individual to an organisation depends on the degree to which the organisation's and individual needs are complementary. As Segal (1978:223) states, individuals are said to increase their commitment to an organisation if their own needs are supported by the organisation. This naturally poses a problem for the military organisation which requires a higher degree of personal commitment from their members than other organisations. Obviously operational effectiveness and reliability will be reduced should there be a lack dedication to the profession and the normative values associated 
with military service.

The decline in status and relevance of the profession, together with the erosion of service benefits and tenure appear to be the most crucial factors promoting a decline in the professional service ethic among military personnel in South Africa. In the past, the interests of military personnel were well looked after by government and there was no need to organise into self-interest groups to protect their interests. Should government divest itself from its paternal obligation to the military, it may well see soldiers developing selfinterest behaviour, especially if the military leadership itself fails to address the needs and aspirations of members. It may well be in the interest of military professionalism and stable civil-military relations for the military leadership to reinforce institutional values and with support of the politicians, to guard the interests of their guardians. This may be a worthwhile investment in defence or for defence of democracy in South Africa.

\section{SOURCES}

Caforio G. and Nuciari M. 1994. "The Officer Profession: The ideal-type." Current Sociology, Vol 42 , Number 3, Winter.

Delholm D. and Humes T. 1977. "The case against military unionism" in Sabrosky A. (ed) Blue Collar Soldiers? Foreign Policy Research Institute, United States of America.

Downes C. 1985. "To Be or Not To Be a Profession: The Military Case" in Moskos C and Wood F (ed) The Military More than just a Job? Pegamon-Brassey's International Defence Publishers, Inc.

Janowitz M. 1975. Military Conflict. Sage Publications, Beverly Hills, London.

Jans N. 1988. "Australia." in Moskos C and Wood F (ed) The Military More than just a Job? Pegamon-Brassey's International Defence Publishers, Inc.

Harries-Jenkins G. 1977. "Trade unions in armed forces." in Taylor W., Arango R., and Lockwood R. (ed) Military Unions - U.S. Trends and Issues. Sage Publications, Beverly Hills,London.

Heinecken L. 1994. "Soldiers and Employee Rights: South African Trends and Issues." Strategic Review for Southern Africa, Vol XV1, No 2, November 1994.

Heinecken L. 1995. "Military Unionism in South Africa: Legality and Potential for Development." African Security Review, Vol 4, No 5.

Heinecken L. and Khanyile M. 1996. "Institutional/Occupational Orientations of Students at the S.A. Military Academy". Report on Preliminary Findings, Centre for Military Studies, Military Academy, March.

Huntington S. 1957. The Soldier and the State. The Belknap Press of Harvard University Press. Cambridge, Massachusetts.

Kuhlmann J. 1994. "What do European officers think about future trends, security and missions of 
the armed forces?" Current Sociology, Vol 42, Number 3, Winter.

McAllister I. and Smith H. 1989. "Selecting the Guardians: Recruitment and military Values in the Australian Officer Corps". Journal of Political and Military Sociology, Vol 17, Spring.

Moskos C. 1977. "From Institutional to Occupation - Trends in Military Organisation." Armed Forces and Society, Vol 4, No 1, November.

Moskos C. 1988. "Institutional and Occupational Trends in Armed Forces". in Moskos C and Wood F (ed) The Military More than just a Job? Pegamon-Brassey's International Defence Publishers, Inc.

Moskos C. and Wood R. 1988. "Institution Building in an Occupational World" in Moskos C and Wood F (ed) The Military More than just a Job? Pegamon-Brassey's International Defence Publishers, Inc.

Nuciari M. 1994. "Rethinking the Military Profession: Models of Change Compared". Current Sociology, Vol 42, Number 3, Winter.

Reichart M, and Cilliers J. 1996. "The History of the Homeland Armies." in Cilliers J and Reichart M. About Turn: The Transformation of the South African Military and Intelligence. Institute for Defence Policy, Halfway House.

SANDF 1994. Service Code for Officers.

SANDF 1996. "Defence in a Democracy" White Paper on National Defence for the Republic of South Africa, May.

Segal D. 1978. "Worker Representation in Military Organisation." in Margiotta R. (ed) The Changing World of the American Military. Westview Press, Boulder, Colorado.

Segal D. and Lengermann J. 1980. "Professional and Institutional Considerations". in Sarkesian S. (ed) Combat Effectiveness, Cohesion, Stress and the Volunteer Military. Volume 9, Sage Publications, Beverly Hills, London.

Weibull A. 1994. "European Officers' Job Satisfaction and Job Commitment." Current Sociology, Vol 42, Number 3, Winter.

Wrong L. and McNally J. 1994. "Downsizing the Army: Some policy Implications Affecting the Survivors". Armed Forces and Society, Vol 20, No 2, Winter. 